\title{
Tracing the Cases of Abjection in William Shakespeare's Romeo and Juliet and A Midsummer Night's Dream
}

\begin{abstract}
Amir Andwari
PhD Candidate, School of the Arts, English and Drama, Loughborough University, United Kingdom

Abstract: Being always under threat by what it abjected way back in its pre-Oedipal state, according to Julia Kristeva, the subject (I) should always remain vigilant in order to maintain its identity. However, in many cases, the symbolic world that gives identity to a would-be subject is not what it ideally should be and it is when the subject starts to resist the symbolic and, consequently, it takes refuge in the once abjected semiotic. I believe William Shakespeare's Romeo and Juliet and A Midsummer Night's Dream possess the potential to be approached by Kristeva's psychoanalytic theories regarding the abject, the symbolic, and the semiotic. There are some cases when characters, in some moments of stress, start to resist the symbolic, and, by doing so, they lose vigilance and become vulnerable to the abject.
\end{abstract}

Key Words: The Abject, The Symbolic, The Semiotic,

\section{Introduction}

William Shakespeare's plays have proved themselves proper cases for psychoanalytic criticism, most of which have been directly or indirectly related to Sigmund Freud's theories. Ernest Jones's famous application of Freud's Oedipus Complex to the character of Hamlet paved the way for other practitioners to read Shakespeare with a view to psychoanalytic terms such as the unconscious, repression, id, ego, superego, and uncanny, all of which were developed by Freud. However, as I believe, Shakespeare's plays have the flexibility and potential to be analyzed using, more modern, psychoanalytic concepts, which at the same time review and amend some basic theories of Freud. The tradition of French psychoanalysis began with Jacques Lacan, in whose year-long seminars concepts like the mirror stage emerged. Having been influenced by Freud, Lacan added to and developed the former's theories so that the foundation of post-Freudian psychoanalysis was laid. Among the many thinkers influenced by Lacan, Julia Kristeva proved to be a qualified practitioner in psychoanalysis who succeeded in establishing her own psychoanalytic views, especially in her doctoral dissertation, A Revolution in Poetic Language and also in The Powers of Horror, An Essay on Abjection. In these works, her psychoanalytic theory regarding the symbolic, the semiotic and the abject have been taken into consideration not only in the French canon but also among the Anglo-American practitioners. Taught by Barthes and influenced by Lacan, she has proved herself a leading late twentieth and early twenty-first century thinker, whose theories have been applied to literary works of various genres. In this article, Kristeva's definition of the abject, along with some other key, relevant terms will be addressed and then applied to some characters of two of Shakespeare's plays: Romeo and Juliet and A Midsummer Night's Dream.

Kristeva believes the abject is neither a subject, nor can it be regarded as an object, but "the abject has only one quality of the object - that of being opposed to I" (Powers, 1). The object, with which a child is associated in its early childhood, is jettisoned in a process called abjection. In Kristevan psychoanalysis, the process of abjection occurs before Jacques Lacan's mirror stage, when, as Lacan believes, the little child, between the ages of six and eighteen months, recognizes its own image in the mirror which then helps it to develop a sense of distinct identity. According to Noëlle McAfee, in her book, Julia Kristeva, the abjection process happens "when the infant begins to separate itself from others in order to develop borders between "I" and other. The infant develops these by a process she [Kristeva] calls abjection, a process of jettisoning what seems to be part of oneself" (46). The discarded object, however, is always ready to return when the subject gives it an opportunity to do so. Some people make the mistake of comparing abjection with Freud's notions about the theory of repression; however, it should be noted, "what makes something abject and not simply repressed is that it does not entirely disappear from consciousness. It remains as both an unconscious and a conscious threat to one's own and proper self" (46). In this way, happening before the mirror stage, abjection makes a child free of the 
'other'. This other (or object) is the semiotic stage the child experiences in its pre-Oedipal time. The prelinguistic stage, the semiotic, is governed by bodily drives and has 'mother' as its main representative. The child has to rid itself of this stage in order to enter the symbolic, the real world, which is based on law. In doing so, the infant undergoes a kind of unconscious separation from its mother and treats her as the m(other). In other words, the child has to abject the maternal, its creator, to construct an identity.

One point to consider here is that although the abjection process happens in the early childhood, it is a phenomenon that never entirely recedes and continues to haunt the subject (I) as it grows up to an adult. Abjection continues to "unravel what has been constructed; one's own sense of self is never settled and unshaken" (57), so in order to maintain and protect its own border of subjectivity, a person, in different stages of its life, has to be vigilant against anything that is potentially able to threaten its borders.

Given Kristeva's belief that, unlike repressed desires, what is abjected is never banished altogether and "hovers at the periphery of one's existence, constantly challenging one's own tenuous borders of selfhood" (46), one can use this to explain some Shakespearean characters' moments of epiphany, madness, perplexity, indecisiveness, predicament or even metamorphosis. In such occasions, they surrender to the abjected semiotic. I believe Romeo and Juliet, in Romeo and Juliet, and Lysander, Hermia and Bottom in A Midsummer Night's Dream, in some particular moments, resist the symbolic and, by doing so, face the semiotic. In such moments, they fail to protect their selfhood and, consequently, face the abject.

\section{Cases of abjection in Romeo and Juliet}

\subsection{The case of Juliet}

Kristeva in her essay entitled "Romeo and Juliet: Love-Hatred in the Couple", says that "breaking the law is the initial condition of amatory exaltation: even though the Capulets and the Montagues hate one another" (70). Juliet finds herself with the dilemma of choosing between two suitors, the lawful one and the one who is not. She has a difficult decision to make. Juliet is at the same time unconsciously experiencing a sense of abjection. Although her initial reflection after getting to know the identity of the masked dancer who kissed her is a mixture of fear and despair ("My only love sprung from my only hate." (Shakespeare, I, v. 137)), it does not take long before she decides to ignore the law of her family and fall in love with a Montague. Kristeva says a little child breaks its imaginary, unconscious union with its mother to cleanse itself of the semiotic world and enter the symbolic one. In other words, as Kelly Oliver says, "abjection is a way of denying the primal narcissistic identification with the mother [...]" (60). Juliet expelled her mother a long time ago but the symbolic world she has entered is not as promising as she had (unconsciously) supposed. The symbolic world that was supposed to put her in the realm of subjectivity and give her distinct identity is forcing her to marry Paris, whom she does not love. As an adult, she is observing the unpleasant side of the symbolic. She does not like it. Her decision to reject Paris and marry Romeo marks the second abjection Juliet commits. Actually, by starting to love Romeo, Juliet also rejects the law of her family, which she considers to be both wrong and cruel. She also invites Romeo to think like her:

O Romeo, Romeo, wherefore art though Romeo?

Deny thy father and refuse thy name

Or if though will not, be but sworn my love

And I'll be no longer a Capulet. [...]

'This but thy name that is my enemy:

though art thyself, though not a Montague.

What's Montague? [...]

Romeo, doff thy name,

And for thy name, which is no part of thee,

Take all myself. (Shakespeare, II, ii. 33-49)

Juliet recommends that Romeo 'doff' his name so that they can love each other free from the fear of their families. Juliet ignores her family symbolically to enter the realm of subjectivity she desires.

In addition, the concept of desire and its implications in western culture can pave the way for Juliet to reject not only her family but also social norms and standards. Juliet's desire leaves her no choice but to consummate her secret marriage with Romeo without her family's consent. In his notes on Lloyd Davis' "Desire and Presence 
in Romeo and Juliet", R. S. White writes "Desire is defined by lack or loss, even when it is apparently fulfilled [...]" (43), so the nature of desire itself becomes transgressive. Catherine Belsey in Desire, Love Stories in Western Culture notes "[...] desire is also the location of the resistances to the norms, proprieties and taxonomies of the cultural order" (6). As she continues, "desire, even when it is profoundly conventional, is at the same time the location of a resistance to convention" (7). The feud that exists between the Capulets and Montagues does not let a conventional marriage happen and leaves the couple with no choice but to break the law of their families. Arthur Brooke in his preface to Romeos and Juliet considers the lovers as lawbreakers who surrendered to their "unhonest desire, of the neglect of authority and parental advice, the shame of the stolen contracts, the moral to be drawn by the pious readers [...]" (qtd. in Shakespeare, 36). Therefore, the nature of the couple's transgressive desire is at odds with the social norms of their time. Belsey believes that "desire in Western culture thus demonstrates the inability of the cultural order to fulfill its own ordering project and reveals the difficulty with which societies control the energies desire liberates" (7).

As a result, one can arrive at this notion that desire serves as a major force that pushes Juliet to undergo abjection. As Kristeva considers law breaking a prerequisite to reach 'amatory exaltation', Juliet, though described as a "holy shrine" (Shakespeare, I, v. 93) by Romeo when they first meet, does not consider it a sin to give in to Romeo.

\subsection{The Case of Romeo}

$\mathrm{O}$, she doth teach the torches to burn bright!

It seems she hangs upon the cheek of night

Like a rich jewel in an Ethiope's ear; [...]

Did my heart love till now? forswear it, sight!

For I ne'er saw true beauty till this night. (Shakespeare, I, v. 43-52)

Romeo says these lines at Capulet's feast, when his eyes for the first time catch sight of Juliet. While his eyes are fixed on her, he is experiencing a peculiar, uncanny sensation that is comparable to an epiphany. Robert Lanier Reid, in Shakespeare's Tragic Form, Spirit in the wheel believes Romeo and Juliet, in the opening act, experience a kind of "matching epiphany-series" in "their initial encounter when they immediately pledge love in a mutually-devised sonnet ending in kisses, [...]" (79-80). I assume that the above soliloquy makes the readers aware of the young Montague's going through a kind of sudden and striking realization (epiphany) that serves as the starting point of his burning desire for Juliet. What occurs at the same time is the fading away of his love for Rosaline, with whom Romeo was desperately in love before seeing Juliet. The question that arises here is whether it is just the beauty of Juliet that enchants him or there may be another reason about which Romeo has no conscious knowledge.

The moment Romeo sees Juliet, his subjectivity fails to be vigilant against the semiotic drives that threaten his selfhood. The recollections of his semiotic stage have continued to exist on the other side of his subjectivity border and do not leave the adult-Romeo alone. Now that Romeo is in love, the border is not well guarded and, inevitably, he gives in to the semiotic. What happens to Romeo is an unconscious remembrance of his preOedipal stage when he was associated with his mother. Therefore, the moment Romeo sees Juliet is the moment he experiences the reminiscences of his abject mother approaching this time to enchant him and push him to go through all the consequences that Juliet's love would bear.

In my view, the nature of Romeo's desire has an important role in drawing him toward abjection. Nearly all critics are of this opinion that Romeo and Juliet's desire is transgressive. Their love is a violent, ecstatic, and overwhelming force that supplants all other values. Kristeva herself calls their love transgressive and illicit. Actually, this transgressive love/desire is strong enough to have Romeo ignore the law and convention of his family. While talking about the nature of Romeo's desire, it is necessary to refer to George Bataille, whose views regarding desire in western culture inspired Kristeva to write The Powers of Horror. White says "the writing of Georges Bataille lies behind some of the psychoanalytic readings of Romeo and Juliet. He provides an extreme example of the thesis that desire is inherently transgressive and linked with violence" (13-14). According to Bataille, a lover loves his beloved so violently that for him the proximity of love and death reaches a critical point. I believe that Romeo observes such proximity. Although White thinks Bataille goes too far in 
defining desire and considers it inextricably associated with taboos and death, some aspects of the latter's views are quite relevant to Romeo's desire. Bataille in Erotism: Death \& Sensuality says:

Possession of the beloved object does not imply death, but the idea of death is linked with the urge to possess. If the lover cannot possess the beloved, he will sometimes think of killing her; often he would rather kill her than lose her. Or else he may wish to die himself [...]. If the union of the two lovers comes about through love, it involves the idea of death, murder or suicide. This aura of death is what denotes passion [...] (20)

While some thinkers (especially the cultural materialists) reject the above psychoanalytic approach and believe that Romeo does not chase death and that he is just unlucky, it is worth bearing in mind that his desire to possess Juliet is plagued with death from the moment of its inception. Juliet's love seems to push him to love and violence. Upon his entering the Capulet feast, while watching Juliet, he narrowly escapes being murdered by Tybalt. He, and also Juliet, are plagued with thoughts of suicide. In act III, in Friar Lawrence's cell, he threatens to stab himself with a knife after he sees his union with Juliet under threat because of his ensuing banishment. Romeo's behavior puts a true mark on Bataille's belief that in western cultures, in moments of despair and hopelessness, urged by their transgressive desire, lovers often think of death and suicide.

McAfee believes that guarding the borders of its subjectivity is the most important concern of a subject and states that "to keep hold of oneself, a subject has to remain vigilant against what may undermine its borders" (57). Therefore, a subject (a particular person with a fixed identity) must always take care of its territory so that it remains immune against the possible threat of what was abjected before. However, sometimes, in particular moments, such as when a person falls in love, the abjective penetration becomes inevitable. Therefore, Romeo, in his moment of epiphany at the end of scene I, at best, plays the role of a Kristevan subject who encounters the abject.

\section{Cases of Abjection in A Midsummer Night's Dream}

\subsection{The case of Hermia and Lysander}

Many critics have noted that Shakespeare's depiction of Lysander and Hermia's love is, in fact, a parody of Romeo and Juliet's strong desire towards each other. However, at least in the first scene, there is no sense of a parody. The two Athenian lovers face the same situation as do the Veronese lovers: "the will of a father against the desire of his daughter" (Bate, 133). The Athenian lovers' reactions, when they find union difficult, promises the audience an even more catastrophic ending than that of Romeo and Juliet. When they talk together alone in act I, scene i, they decide to elope, and, also, their conception of love is full of images of destruction and violence. As J. Dennis Huston says in "Bottom Waking: Shakespeare's Most Rare Vision", "in a single speech Lysander talks of war, death, sickness, siege, shadows, collied night, the jaws of darkness, and quick bright things come to confusion" (216). These images seem to make the situation similar to that of Romeo and Juliet. Huston continues:

Such imagery suggests the language of two other young Shakespearean lovers, Romeo and Juliet, who have a similar fascination with disaster but who inhabit a world which tragically matches the image of their minds with a corresponding violence. No such violence fortunately is available to the lovers in this dramatic world; for here potentially destructive impulses are diffused in the play [...] (217)

Also Nigel Wood in "Spleen in Shakespeare's Comedies" emphasizes the fact that a catastrophe will not happen because "we know we are watching a comedy, so such skepticism is presumably diluted by the inexorability of the fortunate ending; [...]" (143). Therefore, because Shakespeare aims to end the play as a typical comedy does, the lovers are fortunate enough to celebrate their union at the final scene of the play.

I think Lysander, and especially Hermia, because their situation is similar to that of Romeo and Juliet, undergo the same psychoanalytic process that the Veronese lovers do. Like Juliet's father, Egeus has found Hermia a husband, Demetrius, and tells Theseus, the Duke of Athens, "this man hath my consent to marry her" 
(Shakespeare, I. i, 25). Her predicament seems even worse than that of Juliet. When Egeus tells Theseus that his daughter wants to marry Lysander, Theseus threatens Hermia with the Athenian law, according to which she must be obedient to her father, otherwise she has to choose between death or the life of a nun. Lysander's solution is to escape Athens to a place where, "there, gentle Hermia, may I marry thee, and to that place the sharp Athenian law cannot pursue us" (I, i, 161-163).

As far as Kristeva's psychoanalysis is concerned, 'the sharp Athenian Law' can be considered a characteristic of the symbolic world the lovers entered after abjecting their semiotic ties. They established their subjectivity a long time ago (after they abjected the semiotic) and have so far lived in the realm of the symbolic. However, as Kristeva believes, what is abjected always stays at the border of subjection and waits for an opportunity for penetration. Here, as I believe, in order to get married, Hermia and Lysander have to escape the symbolic world and enter the realm of the semiotic. The world of the semiotic is a world in which the law of the father does not exist. Therefore, the couple's escape to the forest is a journey from the symbolic (the Athens and its law) to the semiotic (the forest and its freedom). However, according to Kristeva, the semiotic process cannot last long and one has to return to the realm of the symbolic after a while. Fortunately, in this play, as it is a comedy, when the lovers are called to return to Athens, Theseus convinces Egeus to accept Lysander as his son in law and, by doing so, paves the way for the couple to get married.

\subsection{The case of Bottom}

Nick Bottom, the weaver, though a minor character in the play, becomes involved in one of the most impressive Shakespearean scenes. Although Ronald F. Miller in "A Midsummer Night's Dream: The Fairies, Bottom, and the Mystery of Things" mentions "[...] Bottom acts as if the imagination did not exist at all" (261), ironically he undergoes the most fascinating and imaginative experience among the others. His Ovidian-like metamorphosis to a man wearing the head of an ass, although it frightens his friends, attracts the attention of Titania, the queen of the fairies, whose eyes are anointed by the pansy juice. His adventures among the fairies and what he recalls when he wakes up in the morning put Bottom among those Shakespearean characters about whom Kristeva's views regarding abjection are fully applicable. The moment he wakes up in the forest, he cannot remember what happened to him the night before, he is perplexed:

I have had a most rare vision.

[...] The eye of

man hath not heard, the ear of man hath not seen,

man's hand is not able to taste, his tongue to

conceive, nor his heart to report, what my dream was. (Shakespeare, IV, i. 203-212)

I believe what Bottom cannot remember is his having been with his m(other) (manifested by Titania) the previous night. Actually, what '[...] not heard [...] not seen' is his experience of the semiotic. In my view, Bottom's speech in his state of perplexity, after he wakes up in the morning, is a good example of a subject who has experienced alterity (or the other). Shakespeare, by letting Bottom experience the world of the fairies, gives him the opportunity to experience his pre-mirror stage. Huston believes in the same way:

That is [...] what Shakespeare is doing when he wakens Bottom from charmed sleep. He is bringing Bottom back from the diffusive world of sleep and dream, from the identityobliterating fantasies of Titania's bower and a time, in the pleasures of earliest infancy, when self and world were undifferentiated. (221)

'The pleasures of earliest infancy' could serve as a good description for the semiotic state a child lives in in its early infancy, a dream like state in which there is no fixed identity. Bottom's asininity gives him the opportunity to experience the semiotic state he used to associate himself with when he was a child. The semiotic beginning he was associated with once but had to expel that in order to enter the real, symbolic world. The moment he wakes up, he cannot remember anything at first. He is perplexed. All the things that happened to him the night before seem to have been a 'rare vision', something extraordinary and beyond the grasp of human beings. 


\section{Conclusion}

Finally, I maintain that A Midsummer Night's Dream and Romeo and Juliet gave me some examples of moments of abjection experienced by different characters. Moments when the characters resist the symbolic and open their borders of subjectivity for the semiotic elements. Shakespeare skillfully creates such moments when his characters experience love, epiphany, metamorphosis, perplexity and alterity, all of which lead them to experience abjection. In the above-mentioned plays, the Veronese and Athenian lovers, plus Bottom, in particular moments, in contrast to what they did in their pre-mirror stage moments, expel the symbolic and, by doing so, embrace the semiotic. The semiotic helps them to achieve what seems impossible at the beginning of the plays. However, as they are at the mercy of Shakespeare's manipulations, while the abject pushes Romeo and Juliet to a tragedy, the forest dwellers' temporary abjections bring about a comedy.

\section{Acknowledgements}

I would like to thank my supervisors in Loughborough University, Professor Nigel Wood and Dr. Joan Fitzpatrick, without whose support I could not write and share this paper.

\section{Works Cited}

[1] Bataille, Georges. Erotism: Death \& Sensuality. Trans. Mary Dalwood. 1st City lights ed. San Francisco: City Lights Books, 1986. Print.

[2] Bate, Jonathan. Shakespeare and Ovid. Oxford; New York: Clarendon Press ; Oxford University Press, 1993. Print.

[3] Belsey, Catherine. Desire, Love Stories in Western Culture. Oxford; Cambridge (Massachusetts): Blackwell, 1994. Print.

[4] Davis, Lloyd. "Death-marked love: Desire and Presence in Romeo and Juliet." Romeo and Juliet: Contemporary Critical Essays. Ed. R.S. White. New York: Palgrave, 2001. 85-115. Print.

[5] Huston, J. Dennis. "Bottom Waking: Shakespeare's Most Rare Vision.” Studies in English Literature 13.2 (1973): 208222. Web. 17 December 2014.

[6] Kristeva, Julia. "Romeo and Juliet: Love-Hatred in the Couple." Romeo and Juliet: Contemporary Critical Essays. Ed. R.S. White. New York: Palgrave, 2001. 68-84. Print.

[7] Kristeva, Julia. The Powers of Horror: An Essay on Abjection. New York: Columbia University Press, 1982. Print.

[8] Kristeva, Julia. Revolution in Poetic Language. Trans. Margaret Waller. New York: Columbia University Press, 1984. Print.

[9] McAfee, Noëlle. Julia Kristeva. New York: Routledge, 2004. Print.

[10] Miller, Ronald F. "A Midsummer Night's Dream: The Fairies, Bottom, and The Mystery of Things." Shakespeare Quarterly 26.3 (1975): 254-268. Web. 17 December 2014.

[11] Oliver, Kelly. Reading Kristeva: Unraveling the Double-bind. Bloomington: Indiana University Press, 1993. Print.

[12] Reid, Robert Lanier. Shakespeare's Tragic Form: Spirit in the Wheel. Newark: London; Cranbury, NJ: University of Delaware Press ; Associated University Presses, 2000. Print.

[13] Shakespeare, William. A Midsummer Night's Dream. The Arden Shakespeare. Ed. Harold F. Brooks. London: Methuen \& Co., 1979. Print.

[14] Shakespeare, William. Romeo and Juliet. The Arden Shakespeare. Ed. Brian Gibbons. London, New York: Methuen \& Co., 1980. Print.

[15] White, R.S. "What Is This Thing Called Love?" Romeo and Juliet: Contemporary Critical Essays. Ed. R.S. White. New York: Palgrave, 2001. 1-27. Print.

[16] Wood, Nigel. "Spleen in Shakespeare's Comedies." The Renaissance of Emotion: Understanding Affect in Shakespeare and his Contemporaries. Eds. Richard Meek and Erin Sullivan. Manchester: Manchester University Press, 2015. 143170. Print. 